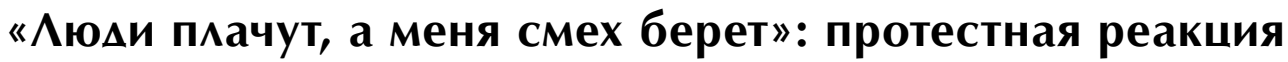 спецпоселенцев Томской области на смерть И. В. Сталина
}

Ольга Вячеславовна Фимиппенко

Новосибирский государственный университет экономики и управления, Россия, г. Новосибирск, https://orcid.org/0000-00019287-196X; olga.kanyshkova@mail.ru

Поступика в реАакцию 16.10.2021. Принята посме рецензирования 08.12.2021. Принята в печать 13.12.2021.

Аннотация: В статье поднимается проблема активизации протестных настроений спецпоселенцев Томской области в первые месяцы после получения ими известия о болезни и последующей смерти И. В. Сталина (март-апрель 1953 г.). Исследование базируется на спецсообщениях Управления МГБ по Томской области, зафиксировавших размичные формы «антисоветского» поведения депортантов. Их анализ показывает степень аАаптивности спецпоселенцев к требованиям власти и позволяет оценить их способность придерживаться установленных политических ритуалов по имитации своей мояльности к системе, Ааже в тех ситуациях, когАа позиции режима явно ослабли. ПосреАством анализа санкций, наложенных на спецпоселенцев, дается характеристика поведения работников местных карательных структур в условиях практически полного отсутствия инструкций. Исследование завершается выводом, что «антисоветское» поведение депортантов явцялось не столько целенаправленным протестом, сколько иррациональной реакцией отдельных депортантов на экстраординарное событие. Реакция сотрудников регионального отделения МГБ на подобные Аействия соответствовала не новому курсу советской политики, а сформированным на протяжении сталинской эпохи поведенческим шаблонам, согласно которым нарушители выявлялись, а затем жестко и показательно наказывались. Ключевые слова: спецпосемение, этнические депортации, поздний сталинизм, протестное поведение

Цитирование: Филиппенко О. В. «ИюАи плачут, а меня смех берет»: протестная реакция спецпоселенцев Томской области на смерть И. В. Сталина // Вестник Кемеровского государственного университета. 2021. Т. 23. № 4. С. $920-928$. https://doi.org/10.21603/2078-8975-2021-23-4-920-928

\section{Введение}

Смерть И. В. Сталина потрясла все советское население, разрушима привычный порядок жизни и ознаменовала собой конец эпохи. Царившие в обществе настроения неопределенности ярко переданы в воспоминаниях Ривки Рабинович, бывшей ссыльнопосеменки, Аепортированной из Аатвии в Томскую область в 1941 г.: «Сталин был постоянным фактором в нашей жизни, подобно восходу и закату солнца. Казалось, что порядок мироздания поколебался. ОАин из официальных мозунгов пропаганды гласил: "Аенин всегАа с нами". Хотя этот мозунг можно было видеть везде, Ааже в классах школы, присутствие $\Lambda$ енина мы не ощущали, он межал в мавзолее и никому не мешал. В противоположность этому Сталин действительно был всегАа с нами. НароА привык к тому, что все Аелается по указаниям "сверху". На кажАом уровне свой "верх" - сельский, районный, областной, республиканский, всесоюзный. А всесоюзный верх - это Сталин. Такова структура власти. И вАруг верха этой структуры больше нет. Кто же буАет управцять страной? Неизвестность внушала страх» [1, с. 180]. В атмосфере неопределенности оказались не только рядовые гражАане, но и преАставители вцасти, привыкшие неукоснительно выполнять указания центра, но вынужденные Аействовать в условиях их фактического отсутствия.

В историографии смерть И. В. Сталина рассматривается, прежде всего, как начало нового периода советской истории. По этой причине акцент в анализе ставится не на первоначальной реакции гражАан на это событие, а на его Аолгосрочных последствиях. В то же время Аостаточно подробно рассматриваются баталии, развернувшиеся в высших кругах власти в марте 1953 г. Среди биографов И. В. Сталина ведутся активные, хотя и не всегда беспристрастные, Аискуссии о причинах его смерти и хронологии событий на Ааче в Кунцево [2, S. 487-497; 3; 4, p. 861-868; 5, p. 1-35; 6, p. 700-743; 7, c. 199-223; 8; 9; 10, c. 103-108; 11]. Эволюция идеологических установок и другие изменения, произошеАшие в обществе в три первых месяца после смерти вожАя, все еще остаются плохо изученными.

ОАнако в историографии есть отАельные статьи, заскуживающие особого упоминания. А. П. Куропаткин, проанализировав изменения советской пропаганды весны 1953 г., пришел к выводу, что уже в течение первых ста Аней после смерти И. В. Сталина произошел отказ от культа Аичности вожАя и усилилось «безмичное» направление в советской иАеологической политике [12, с. 168]. ОАнако, по мнению историка, этого времени было неАостаточно Аля того, чтобы рядовые граждане приняли изменения: Аюди продолжаки жить по ранее сформированным канонам [13, с. 100 101]. Это отчасти противоречит мнению Ю. А. Зумяра, отметившего, что Аесталинизация в вузах Иркутска начала ощущаться уже весной 1953 г., что проявицось 
в прекращении идеологических кампаний и поисков носителей «чужАых» взгляАов, а также снятии наложенных партийных взысканий [14, с. 233]. Рассматривая траурные мероприятия весны 1953 г. как полноценную идеологическую кампанию, Ю. В. Костяшов пришел к выводу, что партийные организации и комитеты всех уровней практически не функционировали в течение месяца после смерти вожАя. По этой причине на территории КамининграАской области практически не проводимось митингов, собраний и пикетов, кампания ограничивамась публикацией различных траурных материалов на страницах газет и выпуском тематических радиопрограмм $[15$, с. 81$]$. Подобные тенАенции быми характерны дмя Новочеркасска, где в течение марта 1953 г., парткомитет города заседал трижАы, но вопрос о И. В. Сталине не поднимался [16, с. 62]. Иная ситуация сложилась в Кемеровской области: согласно данным Е. С. Гениной и М. М. Комязимовой, там проходили многочисленные траурные шествия, на которых присутствовало более 900 тыс. человек [17, с. 148]. Подобные выводы были саеланы В. А. Король в отношении Белорусской ССР [18, с. 195-196]. Эти диаметрально противоположные сведения показывают, что местные власти по-разному отреагировали на текущую атмосферу неопределенности. ОАни были настолько деорганизованы, что практически не преАприняли никаких мер по организации траурных мероприятий, Аругие, напротив, сумели относительно быстро сориентироваться и мобилизовать население.

Проблема активизации протестного поведения советского населения в марте 1953 г. была рассмотрена в комментариях к сборнику документов, посвященному инакомыслию в СССР 1953-1982 гг. Автор вступительной статьи к нему В. А. Козмов отметиц, что сразу после смерти вожАя власти по старой привычке провели репрессивную кампанию А^я подАержания общества в напряженном состоянии. По ее итогам были арестованы отдельные мица, забывшие на мгновенье о «правилах безопасности» и позволившие себе сказать что-то нелицеприятное об усопшем вожде. При этом историк подчеркнул, что подобное протестное поведение было скорее искиючением, чем правилом. В целом публичное выражение своего негативного отношения к И. В. Сталину рядовые гражАане воспринимали как кощунство. В этой связи мица, вставшие весной 1953 г. на сторону протеста, рассматриваются В. А. Козмовым как одиночки, выступившие против «комлектива» Аояльных подАанных. Амя молчаливого большинства они были изгоями и врагами, подлежащими заслуженному наказанию [19]. Схожие паттерны поведения были характерны Аля граждан Аружественных СССР стран, например Китая [20, с. 81-85].
В рамках настоящей статьи большое внимание уделяется протестным реакциям спецпоселенцев на смерть И. В. Сталина, поскольку они показывают, насколько сильно «небкагонадежные» эмементы усвоили установменные в советской системе правила игры. Аругими словами, если будет Аоказано, что Аепортанты Ааже в ситуации, когАа власть явно ослабла, а население ожидало серьезных изменений, продолжали придерживаться ритуала или по крайне мере имитировать кояльность к системе, то можно преАположить, что они были способны аАаптироваться к существовавшим требованиям. Не менее важна и реакция региональных властей на протестное поведение спецпоселенцев: анализ санкций, наложенных на нарушителей правопорядка, покажет, Аействовали ми сотруАники надзорных органов в соответствии со старыми повеАенческими шаблонами, и насколько они были готовы защищать старый порядок. Это в свою очередь актуализирует проблему функционирования Аиктатур в кризисных ситуациях. Исходя из этого, цель настоящей статьи была сформулирована следующим образом: выявить основные формы протестного поведения, характерные Амя спецпоселенцев в марте-апреле 1953 г., и сопоставить с последующими за ними наказаниями.

Основу источниковой базы исследования составмяют спецсообщения, направленные начальником управления МГБ по Томской области Н. С. Великановым секретарю Томского обкома КПСС И. А. Смольянинову ${ }^{1}$. Источники Аатируются преимущественно 7-14 марта 1953 г. и содержат описания фактов «антисоветской» Аеятельности правового населения и спецпоселенцев, произошеАших, как правило, 4-8 марта. В рассматриваемых Аокументах описано 20 случаев протестного поведения Аепортантов, и в качестве их участников поименно называются 26 человек. Кроме того, было обнаружено одно спецсообщение, в котором фигурирует восемь выдержек из частных писем спецпоселенцев ${ }^{2}$. Несмотря на крайне низкую репрезентативность используемых Аокументов (всего на 1 июля 1950 г. на территории Томской области было расселено 56604 спецпоселенца ${ }^{3}$ ), Аанный источник преАставляется крайне ценным, поскольку показывает едва ми не первую реакцию Аепортантов на рассматриваемые события, что отличает его, например, от воспоминаний.

Фигурирующие в спецсообщениях мица были сопоставмены с книгой памяти по Томской обкасти ${ }^{4}$. В результате этого была не только дополнена формальная информация о жизни Аепортантов, но и частично прослежена их Аальнейшая судьба. Помимо этого, в базе воспоминаний, собранной мемориальным музеем «СлеАственная тюрьма НКВА» г. Томск, бымо обнаружено интервью с оАним

\footnotetext{
${ }^{1}$ Центр Аокументации новейшей истории Томской обкасти (ЦАНИ ТО). Ф. 607. Оп. 1. А. 1923 (2). А. 207-216, 225-230, 252-256, 262-266, 310-315.

2 Там же. $\Lambda .270-272$.

${ }^{3}$ Государственный архив Томской области (ГАТО). Ф. Р-9479. Оп. 1. А. 556. А. 16.

${ }^{4}$ Боль люАская: Книга памяти томичей, репрессированных в 1930-е - начале 50-х годов / поА реА. В. Уйманова. Томск: ИзА-во Томского университета, 2016. T. 1-3.
} 
из спецпоселенцев, который упоминается в спецсообщениях, Самуиком $\Lambda$ ьвовичем Зиссером ${ }^{5}$. Интервью взял Аба Таратута в Иерусалиме в марте 2003 г., когда С. $\Lambda$. Зиссеру было 82 года. Спецпоселенец родился в Москве, его отец быи евреем и месопромышиенником из Риги, мать - немкой. После вхождения $\Lambda$ атвии в состав СССР отец С. $\Lambda$. Зиссера был направлен в магерь на 10 мет, а он вместе с матерью был выслан на север Томской области, в Компашево, гАе работал скрипачом. После войны он получим разрешение на выезА в Томск, гАе трудоустроился в местной филармонии. 9 марта 1953 г. он вместе с матерью был арестован за контрреволюционный саботаж и уже 11 июня 1953 г. быи приговорен к 25 годам исправительно-трудовых магерей. ВпослеАствии в ходе пересмотра Аела срок заключения был снижен до 10 мет. В 1973 г. он с семьей эмигрировал в Израиль. Это интервью позволико понять, какая мичность стояла за формальными документами МГБ.

\section{Состав «протестующих» спецпосеменцев}

Возраст названных в спецсводках МГБ депортантов преАставмен в табл. $1^{6}$. По большей части протестное поведение было характерно Аля тридцати- и сорокалетних депортантов. Только одному спецпоселенцу в момент высылки было девять мет, еще Авоим - 17 и 19 мет. СлеАовательно, обвиненные в «антисоветской» Аеятельности депортанты имели богатый жизненный опыт и уже выработанные модеки поведения. Им, по сравнению с поколением, выросшим в спецпоселках, было намного труднее принять новые правика жизни.

При анализе гендерного состава исследуемой группы спецпоселенцев был выявлен перекос в пользу мужчин $(61,5 \%)$. Это не обязательно было связано с тем, что мужчины

Табл. 1. Возраст спецпосеменцев, обвиненных в «антисоветской» Аеятельности в 1953 г.

Tab. 1. Age of deportees accused of "anti-Soviet" activities in 1953

\begin{tabular}{|c|c|c|c|c|}
\hline \multirow{2}{*}{ Возраст } & \multicolumn{2}{|c|}{1953} & \multicolumn{2}{|c|}{$\begin{array}{c}\text { На момент } \\
\text { Аепортации }\end{array}$} \\
\hline & $\begin{array}{c}\text { Комичество } \\
\text { человек }\end{array}$ & $\%$ & $\begin{array}{c}\text { Комичество } \\
\text { человек }\end{array}$ & $\%$ \\
\hline Ао $10 \Lambda е т$ & - & - & 1 & 7,6 \\
\hline $10-19$ мет & - & - & 2 & 15,4 \\
\hline 20-29 мет & 4 & 18,2 & 4 & 30,8 \\
\hline 30-39 мет & 7 & 31,8 & 2 & 15,4 \\
\hline 40-49 мет & 6 & 27,3 & 4 & 30,8 \\
\hline 50-59 ^ет & 3 & 13,6 & - & - \\
\hline 60-69 мет & 2 & 9,1 & - & - \\
\hline Всего & 22 & 100 & 13 & 100 \\
\hline
\end{tabular}

были более скмонны к выбору протестной модели поведения. Во-первых, работники МГБ могли чаще фиксировать «антисоветскую» Аеятельность мужчин, обращая меньшее внимание на протестное поведение женщин. Во-вторых, описывая враждебные настроения всей семьи, органы МГБ могли приводить в пример только высказывания главы семьи, которыми чаще всего явмялись мужчины. Например, в спецсообщении, в котором органы МГБ зафиксировами «антисоветские» высказывания упомянутого выше спецпосеменца С. $\Lambda$. Зиссера, ничего конкретного не сообщается о поведении его матери, хотя она была осуждена вместе с ним и приговорена к 10 годам заключения и 5 годам поражения в правах. В источнике фигурирует только следующая фраза: «Зиссер, [имя Аругого спецпоселенца] и связанные с ними мица, всего в количестве четырех человек, арестованы и привлекаются к уголовной ответственности ${ }^{7}$.

Информация о типах контингентов спецпоселенцев была установлена в отношении 19 человек. ПоАавляющее большинство спецпоселенцев были депортированы из Аитвы (5 человек) или Аатвии (7 человек). С этих территорий проводились Аве крупные депортационные кампании. Первая - июньская Аепортация 1941 г., проведенная после вхождения прибалтийских стран в состав Советского Союза. Вторая кампания, т. н. операция «Прибой», была проведена в марте 1949 г. Как минимум 5 ссыльных были депортированы в 1941 г., как минимум 2 - в 1949 г. Следовательно, спецпоселенцы, высланные из Аитвы и Аатвии, были более скмонны к проявмению протестного поведения в сравнении с Аругими спецконтингентами, а степень их мояльности не зависела от срока пребывания в ссылке. По Ава человека принаАлежали к «ссыльнопоселенцам из Украины» (высылка 1941 г.), репатриантам и «немецким пособникам» (высылка 1945 г.), еще один спецпоселенец был преАставителем «свидетелей Иеговы» (высылка 1951 г.). СреАи исследуемых спецпоселенцев нет преАставителей советских немцев и каммыков, хотя именно они являмись оАними из самых массовых категорий Аепортантов в Томской области.

Принадлежность к спецконтингенту не всегда отражала национальность человека. Например, в состав «ссыльнопоселенцев из $\Lambda$ атвии» часто входили не только матыши, но и евреи, китовцы, помяки и немцы. Согласно табл. $2^{8}$, протестное поведение было характерно Аля митовцев, матышей и немцев. Следовательно, подобный тип протестного поведения был свойственен мицам, Аепортированным из западных регионов, в основном из Прибалтики. Остальные спецпоселенцы были более мояльны и могли, по крайне мере внешне, придерживаться установменных правик.

\footnotetext{
${ }^{5}$ Интервью с Самуиком Зиссером (провел Аба Таратута в марте 2003 г.) // Мемориальный музей «Следственная тюрьма НКВА». Режим доступа: http://nkvd.tomsk.ru/projects/posledniysvidetel/writings/zissersl/ (Аата обращения: 15.10.2021).

${ }^{6}$ Составлено по: ЦАНИ ТО. Ф. 607. Оп. 1. А. 1923 (2). А. 207-216, 225-230, 252-256, 262-266, 270-272, 310-315.

7 Там же. $\Lambda .207-211$.

${ }^{8}$ Составлено по: ЦАНИ ТО. Ф. 607. Оп. 1. А. 1923 (2). А. 207-216, 225-230, 252-256, 262-266, 270-272, 310-315.
} 
Табл. 2. Национамьность спецпосеменцев, осуществцявших «антисоветскую» Аеятельность

Tab. 2. Nationality of the deportees charged with "anti-Soviet" activities

\begin{tabular}{|l|c|c|}
\hline Национамьность & $\begin{array}{c}\text { Комичество } \\
\text { чемовек }\end{array}$ & \% \\
\hline Армяне & 1 & 4 \\
\hline Евреи & 3 & 12 \\
\hline Аатыши & 5 & 20 \\
\hline Аитовцы & 8 & 36 \\
\hline Момдаване & 1 & 4 \\
\hline Немцы & 5 & 20 \\
\hline Помяки & 1 & 4 \\
\hline Турки & 1 & 4 \\
\hline Всего & $\mathbf{2 5}$ & $\mathbf{1 0 0}$ \\
\hline
\end{tabular}

В Книге памяти фигурирует информация о профессии, образовании и партийной принадлежности спецпоселенцев. Хотя эти данные не явмяются репрезентативными, стоит отметить, что в анализируемую группу входят депортанты с различным уровнем образования (начальное, среднее, незаконченное высшее, высшее). Профессиональный состав рассматриваемой выборки также разнообразен (чернорабочий, токарь, кузнец, бухгалтер, инженер, врач и скрипач). Партийцев в рассматриваемой выборке обнаружено не было.

\section{Формы протестного поведения и реакция вмастей}

В исследуемых источниках названо три формы протеста Аепортантов:

1) отказ участвовать в траурных мероприятиях, проведенных в связи со смертью И. В. Сталина;

2) открытое выражение радости по поводу болезни или смерти вожАя;

3) высказывание «антисоветских» сужАений.

Первая форма преАставлена мишь оАним скучаем, который начамьник Управления МГБ по Томской области Н. С. Великанов описал так: «6 марта 1953 года группа сектантов-иеговистов спецпосеменцев молдаван, работающих в Асиновской МТС, отказались от участия в траурном собрании, посвященным памяти Иосифа Виссарионовича Сталина. На неоднократные приглашения ссыльный Г., 1911 года рожАения, в присутствии рабочих заявик: "На ваших собраниях нам делать нечего... Ваш бог умер, завтра Аругой умрет, а наш бог вечный. Мы только своему богу верим и наАеемся, что кроме его никто не построит хорошей жизни". Г. в числе Аругих участников антисоветской группы намечается нами в ближайшее время к аресту»9 .
Спецпоселенец Г. Аействительно был арестован 23 марта 1953 г. по обвинению в «антисоветской» агитации и приговорен 5 июня 1953 г. к 25 годам исправитемьно-трудовых магерей и пяти годам поражения в правах. ОАнако в октябре 1955 г. он был реабимитирован ${ }^{10}$. Представленная форма протеста была обусловлена религиозными мотивами. Аогматы свидетелей Иеговы подразумевают отрицание земного правительства. По этой причине они не празАнуют светские празАники, отказываются скужить в армии, на государственной службе и т. А. Хотя первая форма протеста не носила массового характера, в ряде случаев значимость соблюдения правил своей веры могла оказываться Аля спецпоселенцев важнее, чем потенциальные риски, связанные с отказом от выполнения требований властей.

Вывод о том, что эта форма протеста не была массовой, подтвержАается информацией о поведении правого населения, которая представлена в исследуемых спецсводках МГБ, - подобных Аанных в них не содержится. Об этом же свидетельствуют и собранные В. А. Козцовым Аокументы. Среди приведенных им случаев проявления протестных настроений назван только один, когАа гражАанин не только отказался пойти на поминальный митинг сам, но и препятствовац Аругим в осуществмении этого: «Пожилой завоАской мастер с Верхней Волги, бывший чмен партии, прежАе судимый по ст. 58 , не пустик рабочих цеха на траурный митинг ("нужно работать, таких митингов будет еще много"), сказац сотруднице: "Не распускай нюни". В момент похорон вожАя решил огласить приказ Аиректора завода о распредемении смен $\gg^{11}$.

Примером второй формы протестного поведения, Аемонстрирующего публичное празднование смерти И. В. Сталина, служит следующая цитата: «4 марта сего года на сборище спецпосеменцев митовцев, работающих в Тимирязевском меспромхозе, группа ссыльных: [Называются фамилии и годы рожАения] с радостью восприняли весть о тяжелой болезни товарища Иосифа Виссарионовича Сталина. При этом Ш. заявила: <...> "Ну, теперь он заболем и может быть ему придет конец". < ...> ПодАерживая ее измышиения присутствовавшая С. ответила: <...> "очень хорошо, что у него парализовало речь, а то бы он переА смертью что-нибудь сказал на нашу шею". < ...> Эти антисоветские выпады подАержал и спецпосеменец П., который пустился в пляс, заявцяя: <..> "Хорошо, что так случилось, может быть он умрет". <...> После этого все присутствовавшие на сборище спецпоселенцы стали петь песни, в которых высказывали змобные антисоветские измышления по аАресу ГАавы Советского Правительства, сопровожАая их нецензурной бранью» ${ }^{12}$. Спецпоселенка С. была арестована 1 апремя 1953 г. по обвинению в контрреволюционной

\footnotetext{
${ }^{9}$ ЦАНИ ТО. Ф. 607. Оп. 1.А. 1923 (2). А. 225-226.

${ }^{10}$ Боль нюаская... Т. 1. С. 319.

${ }^{11}$ Крамома. Инакомыслие в СССР при Хрущеве и Брежневе 1953-1982 гг. / реА. В. А. Козмов, С. В. Мироненко. М.: Материк, 2005. С. 38.

${ }^{12}$ ЦАНИ ТО. Ф. 607. Оп. 1. А. 1923 (2). А. 252-253.
} 
Аеятельности и 17 июня 1953 г. была приговорена к 10 годам исправительно-трудовых кагерей. Реабилитирована она была только в марте 1990 г. $^{13}$

Указанный пример явмяется единственным упоминаемым в источниках случаем, когАа спецпосеменцы публично выражали свою радость по поводу болезни И. В. Сталина. Чаще депортанты праздновали это событие в приватной обстановке. Так, в спецсообщениях приводится смедующее высказывание спецпосеменки М.: «ВАруг сообщают о болезни вожАя, от этих слов мне стало так хорошо на Ауше[,] и я просто не знаца, как Аошиа Ао Аома от радости. А когАа сообщили о смерти [называет имя вожАя], я пришла Аомой и никак не могла АожАаться мужа. И вот П. [муж] пришел такой радостный, что мы все вместе заплакали от такой радости» ${ }^{14}$. Или другой спецпоселенец Р., митовец, 9 марта 1953 г. заявил, что «надо бы выпить за такие радостные события грамм по 200, особенно в 4 часа вечера [примерное время нападения нацистской армии на Советский Союз $]_{\gg}{ }^{15}$. Следовательно, в подавляющем большинстве случаев депортанты продолжали применять выработанные годами аАаптивные механизмы. По этой причине они редко позволяли себе публично выражать свои чувства и пытались скрыть их от посторонних глаз, хотя и не всегда успешно.

Третьей и наиболее распространенной формой протестного поведения было высказывание «антисоветских» сужАений. В них затрагивалось три основные темы:

1) описание своей радости по поводу смерти И. В. Сталина и разъяснение причин своей ненависти к вожАю;

2) высказывание предположений о том, как будет развиваться внутренняя политика;

3) прогнозирование изменений во внешней политике.

Первая тема затрагивается в 16 из 34 высказываний, при этом в 11 из них не объясняются причины ненависти к режиму, спецпоселенцы просто выражают свои положительные эмоции. В этом плане типичными примерами явмяются следующие сужАения: «Аюди плачут, а меня смех берет» ${ }^{16}$, «Узнав это все[,] плясали на одной ноге, и наше сердце чувствует [себя] весемее» ${ }^{17}$, «САава богу [называет имя вожАя и Аопускает по его аАресу оскорбительное выражение] и Советская власть тоже скоро подохнет ${ }^{18}$. Причины ненависти спецпоселенцев в целом могичны и связаны с тем, что в результате деятельности И. В. Сталина «столько невинных мюАей попали в тюрьмы, Аети умирали с голоду[,] и некому было подать кусок хиеба ${ }^{19}$. ЕАинственное, что в этой связи вызывает особый интерес - то, что Аепортанты обвиняют власть в проведении репрессий не столько в отношении своей национальной группы, сколько в отношении всего советского народа. Следовательно, общая трагедия не только объединяла преАставителей различных спецконтингентов, но и стираха грань межАу спецпосеменцами и нерепрессированным насекением.

Поскольку смерть И. В. Сталина разрушила привычный порядок вещей, в своих сужАениях спецпоселенцы активно высказывали предположения о своем будущем и будущем политической системы страны и пытались понять, закрутит ми новая власть гайки еще сильнее или же примет решение об их освобожАении. Эта информация содержится в Аесяти сужАениях.

В семи высказываниях прогноз позитивный: новая власть смягчит режим и позволит спецпоселенцам вернуться Аомой. Аепортанты связывали ссыцку непосреАственно с мичностью И. В. Сталина. Так, спецпоселенка-латышка К. заявила: «Еще один [оскорбительное выражение] умер... самый главный в Москве. После этого все Аела пойдут по[-] Аругому, этот только держал нас здесь ... Нам скоро нужно будет готовиться уехать на родину» ${ }^{20}$. Или спецпоселенец-латыш М. в разговоре с Аругими ссыльными утвержАац следующее: «Обратите внимание[,] какие изменения произошли в Правительстве - все это обнадеживает нас. Сами эти факты говорят в нашу пользу ${ }^{21}$. Кроме того, по мнению ряда спецпоселенцев, оАним из послеАствий смерти И. В. Сталина Аолжна была стать миквидация колхозной системы. Указанное преАположение было высказано «немецким пособником» Т.: «Так, руководитемь партии и правитемьства уже умер. Ничего, правительство все по[-] маленьку подохнет, потом Аля нас, братцы, будет кучше... колхозов не будет, кажАый будет Аелать, что он хочет ${ }^{22}$.

Пессимистические сужАения спецпоселенцы высказывами значительно реже. Эту позицию, например, занял выше упоминаемый С. $\Lambda$. Зиссер, который, согласно Аанным МГБ, в разговоре с Аругим спецпоселенцем А. заявил следующее: «Нет, вот[,] увидите, что Маменков будет вести себя более вызывающе по отношению к великим державам, а внутри страны усилится террор и выселение кюдей из родных

\footnotetext{
${ }^{13}$ Боль мюАская ... Т. 3. С. 153.

${ }^{14}$ ЦАНИ ТО. Ф. 607. Оп. 1. А. 1923 (2) А. 252-256.

${ }_{15}$ Там же. $\Lambda .310-315$.

${ }^{16}$ Там же. $\Lambda .252-256$

17 Там же. $\Lambda .270-272$.

${ }_{18}$ Там же. $\Lambda .310-315$.

${ }^{19}$ Там же. $\Lambda .225-230$

${ }^{20}$ Там же. $\Lambda .262-266$.

${ }^{21}$ Там же. $\Lambda .310-315$.

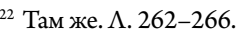


мест $\gg^{23}$. С. $\Lambda$. Зиссер был уже на следующий день арестован и через три месяца был приговорен к 25 годам исправительно-трудовых магерей (наказание было заменено на 10 мет). В своем интервью 2003 г. он практически не рассказывает об обстоятельствах своего ареста. Память явно подводит 82-летнего спецпоселенца: он путает фактические обстоятельства по Аелу. Так, он сообщил, что его арест произошел в 1948-1949 гг., тогАа как по Аанным МГБ и Книге памяти это случилось 9 марта 1953 г. В целом С. $\Lambda$. Зиссер описывает свою жизнь в ссыцке как относительно счастиивое время (хотя у него осталась глубокая обида на Советскую власть, и он воспринимает присоеАинение Аатвии к СССР как оккупацию). По его мнению, в Сибири они «прекрасно жили, не очень мегко, но все-таки неплохо». Особенно его радовац тот факт, что он не был мобилизован в армию, т. к. являлся в глазах власти «антисоветским экементом». В интервью С. $\Lambda$. Зиссер акцентирует внимание не на трудностях кагерной или ссыльной жизни (о голоде он упоминает как бы к слову), а на тех вещах, которые делали его счастливым (работа скрипачом в театре, знакомство с женой). СозАается ощущение, что внешние условия не играли Аля него существенной роли: он практически не рассказывает про материальные и бытовые условия и не помнит ни оАного важного политического события, ни имен руководителей страны. Так, бывший спецпоселенец сообщил, что после смерти И. С. Сталина к власти пришел какой-то человек с начинающейся на «К» фамилией, который прочитал какой-то докмаА. При этом он подробно описывает обстоятельства встречи с женой, процесс изучения им русского языка, переезА в Иркутск после освобождения из магеря. Так, вероятно, сработали защитные механизмы его психики, сохранившие в его памяти мишь те события, которые были связаны с его счастливой частной жизнью ${ }^{24}$.

Спецпоселенцы большое внимание уделили оценке реакции новой власти на смерть вожАя (шесть высказываний). По мнению депортантов, смерть И. В. Сталина была выгодна Аля нынешнего руковоАства, которое устало от репрессий и постоянных перестановок в высших эшелонах власти. Некоторые говорили и об убийстве вожАя. Так, спецпоселенец В. высказал следующую мысль: «Кремль - место темное[,] там много творится. Стоило ввести в организм [называет имя вожАя] препарат, вызывающий высокое кровяное Аавмение[,] и он скончался, но никакие следы не покажут на змоумышиенное умертвмение» ${ }^{25}$. Кроме того, Ава спецпоселенца выдвинули преАположение, что смерть
И. В. Сталина приведет к усилению борьбы внутри элиты: «Я Аумаю, что произойдет еще что-нибудь - произойдет раском ${ }^{26}$; «в Кремле образовалось Ава магеря. Борьба за территорию, борьба межАу Авумя магерями в Кремле ${ }^{27}$.

Аесять Аепортантов высказали мнение о скором обострении ситуации во внешней политике, шесть из них сообщили, что начнется война. При этом война воспринималась позитивно, в ее результате спецпоселенцы должны были непременно получить свободу. Роль Аержавы-освободителя отАавалась Америке и Аругим капиталистическим западным странам, что выглядит вполне Аогично в условиях холодной войны. Аитовец Ш. заявил: « Аюди плачут, а меня смех берет. Все равно скоро будет война. Этот не сумеет руководить... Теперь американцы жАать не будут... А нам, как только услышим про войну, то надо бежать к американцам помогать их [советский народ] бить... Нам надо как-нибудь попасть к передовым миниям и перейти к американцам в плен ... Амя этого надо где-нибудь убить какого[-]нибудь русского и забрать его Аокументы» ${ }^{28}$. Еще трое человек хотя и придерживались точки зрения об обострении отношений межАу США и СССР, но не считали, что это приведет к войне. Последнее, Аесятое, сужАение хорошо Аемонстрирует, насколько сильно было ожидание войны: Аюбое сообщение в исполнении Аевитана ассоциировалось у спецпоселенки М. с ее началом: «В среду 4 марта я ... слышу около нашего магазина голос

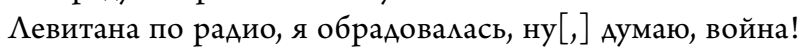
И варуг Сообщают о болезни вожАя ${ }^{29}$.

Миф о внешнем спасителе был характерен Аля сознания Аепортантов на протяжении всей истории спецпоселений. Роль освободителя отдавалась разным странам в зависимости от геополитической атмосферы. В начаме 1930-х гг. по причине конфликта на КВЖА эта функция была возможена на Китай, а с началом войны - на Германию (немцы воспринимались как спасители как минимум до 1946-1947 гг.). С началом холодной войны спецпоселенцы стали связывать свое спасение с капиталистическими странами. Таким образом, свое освобожАение депортанты связывали или с актом Аоброй воли новых правителей, или с военными действиями иностранных государств. Ни один спецпоселенец не высказал мысли, что свободу принесет, например, восстание народа.

В спецсводках названо Ава варианта Аальнейшей судьбы протестантов. В первом случае в источниках указывается, что Аепортанты будут арестованы и привлечены к уголовной ответственности. Эта информация быма подтверждена Аанными Книг памяти (в отношении 5 из 7 рекомендованных

\footnotetext{
${ }^{23}$ Там же. $\Lambda$. 207-211.

${ }^{24}$ Интервью с Самуилом Зиссером ..

${ }^{25}$ ЦАНИ ТО. Ф. 607. Оп. 1. А. 1923 (2). А. 310-315.

${ }^{26}$ Там же. $\Lambda .225-230$.

27 Там же. $\Lambda .310-315$.

${ }^{28}$ Там же. $\Lambda .252-256$.

${ }^{29}$ Там же. $\Lambda . ~ 252-256$.
} 
к аресту человек был вынесен обвинительный приговор). Во втором случае служащие МГБ сообщали, что «в отношении данных спецпосеменцев проводятся мероприятия по вскрытию Аругих фактов их антисоветской деятельности». В Аанном случае наА спецпоселенцами устанавливался усименный административный наАзор. Информация о принятых в отношении депортантов санкциях преАставлена в табл. $3^{30}$.

Табц. 3. Санкции, примененные по отношению к спецпосекенцам Tab. 3. Sanctions applied to deportees

\begin{tabular}{|c|c|c|}
\hline Категория & $\begin{array}{c}\text { Комичество } \\
\text { чемовек }\end{array}$ & $\%$ \\
\hline Не были арестованы & 9 & 26,5 \\
\hline $\begin{array}{l}\text { Быми арестованы и осуждены, в том } \\
\text { числе: }\end{array}$ & 7 & 20,5 \\
\hline $\begin{array}{r}\text { приговорены к } 25 \text { годам ИТА и } 5 \text { годам } \\
\text { поражения в правах }\end{array}$ & 2 & 5,9 \\
\hline $\begin{array}{r}\text { приговорены к } 10 \text { годам ИТА и } 5 \text { годам } \\
\text { поражения в правах }\end{array}$ & 3 & 8,8 \\
\hline нет данньцх & 2 & 5,9 \\
\hline Нет Аанных & 18 & 53,0 \\
\hline Всего & 34 & 100 \\
\hline
\end{tabular}

Примерно пятая часть Аепортантов покучила жесткое наказание. К 25 годам исправительно-трудовых магерей были приговорены С. $\Lambda$. Зиссер («антисоветская» бесеАа) и свидетель Иеговы Г. (отказ принимать участие в траурном митинге), к 10 годам - собеседник С. $\Lambda$. Зиссера. Арестованы были также трое публично выражавших свою радость митовцев. Наказание в виде 10 мет исправительнотрудовых кагерей получила матышка Б. Ее история не явмяется типичной - «антисоветское» сужАение высказал в школе ее сын, ученик 3 класса. Позже он признался, что повторял слова матери и ее Арузей. В Аоме Б. был проведен обыск, в результате которого была найдена «антисоветская» митература ${ }^{31}$. Таким образом, спецпоселенцы получали жесткое уголовное наказание в случае, если их протестное поведение подтвержАалось каким-либо действием (отказ участвовать в собрании; публичное выражение радости; хранение запрещенной митературы). ЕАинственное исключение - история С. $\Lambda$. Зиссера и его товарища. В остацьных случаях спецпоселенцы за ведение «неправильных» бесеА не арестовывались, Ааже если они велись в относительно публичном пространстве.

\section{Закмючение}

Протестное повеАение спецпосеменцев было пассивным, особенно в сравнении с повеАением узников ГУААГа, встретивших смерть И. В. Сталина с большим энтузиазмом и регулярно поднимавших мятежи против режима в течение 1953-1955 гг. [21, с. 204-205; 22, с. 323; 23, с. 443-444]. Аепортанты же не верили в возможность народного восстания. В этой связи можно согласиться с В. А. Козловым [19]: публичное выражение радости бымо не цеменаправленным протестом, а иррациональной и не всегАа контролируемой реакцией мюдей, забывших на время об осторожности. Эти действия не носили массового характера. В целом же спецпоселенцы приспособились к существующим правилам и научились имитировать свою мояльность к системе. Репрессивные акции марта 1953 г. не были инициированы центром. Напротив, преАставители высших эшелонов власти начали последовательно отказываться от прежних практик уже в первые Ани после смерти И. В. Сталина. Была провеАена реформа по объединению МВА и МГБ, созАаны комиссии по рассмотрению особо важных политических Аел и осуществлена амнистия [24, с. 21-22; 25, с. 127-128]. ОАнако смена курса не была четко доведена Ао местных властей, привыкших действовать в соответствии с исходящими из центра нормами. По этой причине весной 1953 г. они начали действовать на основе Аавно выработанного паттерна, в рамках которого мюбого, кто проявит нелояльность нынешней власти, следовало быстро выявмять и показательно наказывать.

Конфмикт интересов: Автор заявил об отсутствии потенциальных конфмиктов интересов в отношении исследования, авторства и / или публикации данной статьи.

\section{Митература}

1. Рабинович Р. Сквозь три строя. М.: Муза творчества, 2015. 520 с.

2. Chlevnjuk O. Stalin: Eine Biographie. München: Siedler Verlag, 2015. 592 S.

3. Kellmann K. Stalins langer Tod / / Der Tod des Diktators: Ereignis und Erinnerung im 20. Jahrhundert / Hg. T. Großbölting, R. Schmidt. Göttingen: Vandenhoeck \& Ruprecht, 2011. S. 100-106.

4. Medvedev R. Let history judge: the origins and consequences of Stalinism. N. Y.: Columbia University Press, 1989. 891 p.

5. Rubenstein J. The last days of Stalin. New Haven, London: Yale University Press, 2016. 271 p.

6. Ulam A. B. Stalin. The Man and his Era. Boston: Beacon Press, 1989. 760 p.

7. Авторханов А. Г. ЗагаАка смерти Сталина: заговор Берия. Frankfurt/Main: Посев, Сop., 1976. 317 с.

8. Жуков Ю. Н. Борьба за власть в партийно-государственных верхах СССР весной 1953 // Вопросы истории. 1996. № 5-6. С. 89-104.

\footnotetext{
${ }^{30}$ Составлено по: Боль АюАская ... Т. 1-3; ЦАНИ ТО. Ф. 607. Оп. 1. А. 1923 (2). А. 207-216, 225-230, 252-256, 262-266, 270-272, 310-315.

${ }^{31}$ ЦАНИ ТО. Ф. 607. Оп. 1. А. 1923 (2). А. 212-213.
} 
9. Зезина М. Р. Шоковая терапия от 1953-го к 1956 году // Отечественная история. 1996. № 2. С. 121-135.

10. Пихоя Р. Г. Советский союз: история власти. М.-Берлин: Direkt-Media, 2019. 655 с.

11. Рейман М. Н. С. Хрущев и поворот 1953 года // Вопросы истории. 1997. № 12. С. 165-168.

12. Куропаткин А. П. Новые направления в идеологической пропаганде в СССР после смерти И. В. Сталина // Известия Самарского научного центра РАН. 2011. Т. 13. № 3. С. 165-169.

13. Куропаткин А. П. Новые веяния в идеологической пропаганде СССР в первые месяцы после смерти Сталина (на материалах передач союзного вещания) // Актуальные проблемы гуманитарных и естественных наук. 2010. № 12. C. 99-101.

14. Зумяр Ю. А. 1953 гоА в истории Иркутского государственного университета // Известия Ааборатории Аревних технологий. 2020. Т. 16. № 1. С. 231-244. https://doi.org/10.21285/2415-8739-2020-1-231-244

15. Костяшов Ю. В. ИАеологические кампании периода позАнего сталинизма в колхозах Калининградской области: история повседневности // Вестник Балтийского федерального университета им. И. Канта. 2012. № 12. С. 75-84.

16. Стариков Н. В. «Мартовский» стресс 1953 года и адаптационный синдром в СССР // Новое прошлое / The New Past. 2017. № 1. C. 57-76. https://doi.org/10.18522/2500-3224-2017-1-57-76

17. Генина Е. С., Комязимова М. М. ИАеологические кампании в СССР 1946-1953 гг., связанные с образом И. В. Сталина (по материалам Кемеровской области) // Вестник Кемеровского государственного университета. 2014. № 3-2. C. $145-150$.

18. Король В. А. Смерть Сталина и реакция жителей Советской Беларуси // Белорусский исторический обзор. 2021. № 1. С. $183-198$.

19. Козиов В. А. Сталин умер! // Крамола. Инакомыслие в СССР при Хрущеве и Брежневе $1953-1982$ гг. / реА. В. А. Козмов, С. В. Мироненко. М.: Материк, 2005. С. 33-36.

20. Hua-yu Li. Reactions of Chinese citizens to the death of Stalin // Journal of Cold War Studies. 2009. № 2. P. $70-88$.

21. Бердинских В. А. Вятлаг. Киров: Кировская областная типография, 1998. 320 с.

22. Иванова Г. М. История ГУААГа, 1918-1958: социально-экономический и политико-правовой аспекты. М.: Наука, 2006. $440 \mathrm{c}$.

23. Эпплбаум Э. ГУААГ. Паутина Большого террора. М.: Московская школа политических исследований, 2006. 608 с.

24. Артюков А. П., Рябов В. В. Преобразования в системе МВА СССР и пенитенциарной системе в марте-июне 1953 года (на материалах Куйбышевской области) // Манускрипт. 2020. Т. 13. № 2. С. 17-22. https://doi.org/10.30853/ manuscript.2020.2.2

25. Аушин А. И., Каминин И. В. Трансформация органов государственной безопасности в период хрущевской «оттепеми» // Гуманитарий: актуацьные проблемы гуманитарной науки и образования. 2019. Т. 19. № 2. С. $125-136$. https://doi.org/10.15507/2078-9823.046.019.201902.125-136

original article

\title{
"People are Crying, but I Can't Stop Laughing": Protest Reaction of the Deportees of Tomsk region to Joseph Stalin's Death
}

\author{
Olga V. Filippenko
}

Novosibirsk State University of Economics and Management, Russia, Novosibirsk; https://orcid.org/0000-0001-9287-196X; olga.

kanyshkova@mail.ru

Received 16 Oct 2021. Accepted after peer review 8 Dec 2021. Accepted for publication 13 Dec 2021.

\begin{abstract}
The research featured special reports from the Tomsk Department of State Security about the "anti-Soviet" protest movement of Tomsk deportees in the first months after Joseph Stalin's death. The analysis revealed how the deportees adapted to the authority demands and imitated their loyalty to the system, even when the regime positions was clearly weakened. The author analyzed the sanctions imposed on the deportees and the behavior of the local punitive officials, who received no instructions from Moscow. Most likely, the "anti-Soviet" behavior was not so much a purposeful protest as an irrational reaction to such an extraordinary event as Joseph Stalin's death. The responsive actions of the Regional Department of State Security did not follow the new course of Soviet policy but rather the behavioral patterns formed during the Stalin era: violators were identified and punished severely and demonstratively.
\end{abstract}

Keywords: political deportees, ethnic deportations, late Stalinism, protest behavior 
Citation: Filippenko O. V. "People are Crying, but I Can't Stop Laughing": Protest Reaction of the Deportees of Tomsk region to Joseph Stalin's Death. Vestnik Kemerovskogo gosudarstvennogo universiteta, 2021, 23(4): 920-928. (In Russ.) https://doi. org/10.21603/2078-8975-2021-23-4-920-928

Conflict of interests: The author declared no potential conflict of interests regarding the research, authorship, and / or publication of this article.

\section{References}

1. Rabinovich R. Through three regimes. Moscow: Muza tvorchestva, 2015, 520. (In Russ.)

2. Chlevnjuk O. Stalin: Eine Biographie. München: Siedler Verlag, 2015, 592.

3. Kellmann K. Stalins langer Tod. Der Tod des Diktators: Ereignis und Erinnerung im 20. Jahrhundert, Hg. T. Großbölting, R. Schmidt. Göttingen: Vandenhoeck \& Ruprecht, 2011, 100-106.

4. Medvedev R. Let history judge: the origins and consequences of Stalinism. N. Y.: Columbia University Press, $1989,891$.

5. Rubenstein J. The last days of Stalin. New Haven, London: Yale University Press, 2016, 271.

6. Ulam A. B. Stalin. The Man and his Era. Boston: Beacon Press, 1989, 760.

7. Avtorkhanov A. G. The mystery of Stalin's death: Beria's conspiracy. Frankfurt/Main: Posev, Cop., 1976, 317. (In Russ.)

8. Zhukov Yu. N. Struggle for power in the party and state leaders of the USSR in the spring of 1953. Voprosy istorii, 1996, (5-6): 89-104. (In Russ.)

9. Zezina M. R. Shock therapy in 1953-1956. Otechestvennaia istoriia, 1996, (2): 121-135. (In Russ.)

10. Pikhoya R. G. Soviet Union: the history of power. Moscow-Berlin: Direkt-Media, 2019, 655. (In Russ.)

11. Reiman M. N. S. Khrushchev and the turn of 1953. Voprosy istorii, 1997, (12): 165-168. (In Russ.)

12. Kuropatkin A. P. New directions in ideological propaganda in the USSR after I. V. Stalin death. Izvestiya of Samara Scientific Center of the Russian Academy of Sciences, 2011, 13(3): 165-169. (In Russ.)

13. Kuropatkin A. P. New trends in the ideological propaganda of the USSR in the first months after Stalin's death (based on the materials of the Union broadcasting). Aktualnyye problemy gumanitarnykh i estestvennykh nauk, 2010, (12): 99-101. (In Russ.)

14. Zulyar Yu. A. 1953 in the history of Irkutsk State University. Reports of the Laboratory of Ancient Technologies, 2020, 16(1): 231-244. (In Russ.) https://doi.org/10.21285/2415-8739-2020-1-231-244

15. Kostyashov Yu. V. The ideological campaigns of the late Stalinism period at kolkhozes of the Kaliningrad region: everyday history. Vestnik Baltiiskogo federal'nogo universiteta im. I. Kanta, 2012, (12): 75-84. (In Russ.)

16. Starikov N. V. "The March stress" of 1953 and the syndrome of adaptation in the Soviet Union. Novoe proshloe / The New Past, 2017, (1): 57-76. (In Russ.) https://doi.org/10.18522/2500-3224-2017-1-57-76

17. Genina E. S., Kolyazimova M. M. Ideological campaigns in the USSR in 1946-1953 connected with the image of J. V. Stalin (revealed by the example of Kemerovo region). Vestnik Kemerovskogo gosudarstvennogo universiteta, 2014, (3-2): 145-150. (In Russ.)

18. Korol V. L. Stalin's death and the response of Soviet Belarus citizens. Belorusskii istoricheskii obzor, 2021, (1): $183-198$. (In Russ.)

19. Kozlov V. A. Stalin is dead! Sedition. Dissent in the USSR under Khrushchev and Brezhnev 1953-1982, eds. Kozlov V. A., Mironenko S. V. Moscow: Materik, 2005, 33-36. (In Russ.)

20. Hua-yu Li. Reactions of Chinese citizens to the death of Stalin. Journal of Cold War Studies, 2009, (2): 70-88.

21. Berdinskikh V. A. Vyatlag. Kirov: Kirovskaia oblastnaia tipografiia, 1998, 320. (In Russ.)

22. Ivanova G. M. History of the GULAG, 1918-1958: socio-economic, political and legal aspects. Moscow: Nauka, $2006,440$. (In Russ.)

23. Applebaum A. The Gulag. Web of the Great Terror. Moscow: Moskovskaia shkola politicheskikh issledovanii, $2006,608$. (In Russ.)

24. Artyukov A. P., Ryabov V. V. Changes in the USSR Ministry of Internal and in penitentiary system in March-June 1953 (by the material of Kuybyshev region). Manuscript, 2020, 13(2): 17-22. (In Russ.) https://doi.org/10.30853/ manuscript.2020.2.2

25. Lushin A. I., Kalinin I. V. Transformation of state security agencies in the period of the Khrushchev's thaw. Gumanitarian: aktual'nye problemy gumanitarnoi nauki i obrazovaniia, 2019, 19(2): 125-136. (In Russ.) https://doi. org/10.15507/2078-9823.046.019.201902.125-136 